\title{
Familial Influence in the Autobiographies of Black South African and African American Women Activists
}

\author{
Monica M. White ${ }^{1}$
}

\begin{abstract}
This essay explores the familial influence on the development of activist identities. In an analysis of the autobiographies of Black South African and African American women activists, the family is explored as a social network that contributes to social activism. The family provides a significant lens by which to explore a largely missing piece in social movement theory - the intimate space of the private world as it relates to resistance. The findings suggest four types of familial influence on resistance identity and strategy: familial modeling of resistance, familial generation of resistance, discursive construction of families, and redefinition of conventional family forms.
\end{abstract}

Key Words: Social movements, women activists, resistance, familial influence, South African, African American, autobiographies

${ }^{1}$ Monica M. White, Ph.D., is Assistant Professor, Department of Sociology, Wayne State University, 2257 Faculty Administration Building, Detroit, MI, 48202. Electronic mail may be sent via the Internet to mowhite@wayne.edu

$\mathbf{F}_{\text {eminist scholars have criticized social movement theory for its male }}$ bias in explaining and understanding resistance. This male bias leads theorists to focus on constructs such as organizational structure and networks, thereby ignoring women's methods of resistance and their participation in liberation struggles. As Kuumba (2001, p. 107) noted, "some resistance strategies engaged in by women as an outgrowth of their productive and reproductive labor are the very ones that are submerged and hidden," (see also Taylor, 1995; Foweraker, 
1995; Aulette \& Mills, 1988; Baver, 1989; Bookman \& Morgen, 1988; Beuchler, 1993; Cohen, 1985). Such analyses challenge the false dichotomy between political and personal spheres of resistance, in which the male sphere of resistance is seen as the political structure and women are conceptualized less as activists because their sphere is seen to be the home. Women's resistance, critics have argued, is "masked by traditional categories used to assess political action" (Naples, 1991, p. 478). A feminist analysis of movement theory suggests that the focus on the public sphere, in which men are seen to exert power and efficacy, should be accompanied by complementary analyses of resistance and activism as they take place in the private realm.

The family is a major private site in which activism occurs. Although the relationship between the family and activism has not been the subject of extensive research, two distinct literatures deal with the topic. One focuses on the nature of the family as a microcosm of the intersection of race, class, and gender that characterizes the public world; activism is seen to develop in response to this microcosm. Not only is the impact of these systems of oppression experienced at the level of the family but "ideas about the family also operate as a cognitive scaffold used to construct intersecting systems of oppression" (Hill Collins, 2000, p. 48). The family illuminates the convergence of social and gendered hierarchies in its struggle to access prestige, economic, social, and political power and serves as an important place for understanding the development of resistance strategies against intersecting systems of oppression.

While some scholars view the family as a microcosm of oppression, others argue that the effects of imperialism and colonialism on the family structure can perpetuate progressive changes in male/female relationships and therefore challenge the assumptions of traditional gender role socialization. Caulfield (1974), for example, explored the non-Western family structure as it is impacted by imperialism. The family, she argued, is the most basic of institutions "involved in the culture of resistance" (p. 73). Through their "creativity and resourcefulness" (p. 69), families develop survival strategies that serve as "the cultural response to imperialism" (p. 69). She posited that families, "generally under the leadership of women, have fought back, defending subsistence production . . . cementing family bonds and building new networks of mutual support . . consolidating and developing cultures of resistancecultures of resistance which, like the role of women and family life itself, have been devalued under imperialist ideology" (p. 74).

Similarly, Baca Zinn (1975), focusing on Chicano families, examined political familism, defined as "the process of cultural and political activism which involves the participation of total family units in the movement for 
liberation" (p. 16). She argued that the Chicano family is the organizing structure for social justice. In addition to their efforts to end social and political oppression in the external society, Chicano families apply the demands and expectations of their liberation struggle to gender-role expectations internally. As a result, women's involvement in movement activities "transform[s] patterns of male exclusiveness" (p. 20).

A second body of literature concerning the family and activism addresses another aspect of the relationship between the family and activism - the functions of roles as resistance. Scholars such as Pardo (1990) explored how family members - in particular, mothers - use their maternal roles as a place of resistance. In her work on Mexican mothers, Pardo noted that "women's activism arises out of seemingly 'traditional' roles" (p. 251) as the women "challenge assumptions of powerlessness of women and static definitions of culture and tradition" (p. 251).

Naples (1991) also extended the construct of motherhood to an understanding of community activists. She argued that community work can be theorized as an enactment of the maternal role in that community activists extend their concern for their own children's welfare to commitment and activism on behalf of collective good and commonwealth. As a result of challenging the established political system, these mother/activists "augment personal and communal empowerment; and "create alternative institutions and organizational processes to increase the power and resources of their community" (p. 479).

The notions that the family structure embodies external systems of oppression and functions as a site, and instrument, of resistance constitute starting points for my investigation of the influence of the family on the development of activist identities. In this essay, I seek to explicate the mechanisms by which the family influences the development of such identities. As a social network that contributes to social activism, the family, I argue, provides a significant lens by which to explore a piece that has been largely missing in social movement theory - the intimate space of the private world as it relates to resistance.

\section{The Autobiographies}

My data for this study are the autobiographies of six Black South African and African American women who were affiliated with the Anti-Apartheid movement in South Africa or in the Black Power movement in the United States. The Black South African women's autobiographies used for this analysis are: Frances Baard's (1986) My Spirit is Not Banned; Winnie Mandela's (1985) Part 
of My Soul Went with Him; and Mamphela Ramphele's (1999) Across Boundaries. The African American women's autobiographies I analyzed are: Angela Davis' (1974) Angela Davis: An Autobiography; Assata Shakur's (1987) Assata Shakur: An Autobiography; and Elaine Brown's (1994) A Taste of Power: A Black Woman's Story.

As social constructionists struggle to understand social movements from the perspective of their participants, autobiographies present a valuable vantage point from which to explore the movement experience. Strauss (1995) emphasizes the importance of the "links between historical events, personal constructions of those events, personal histories and (implicitly) also collective histories" (p. 4). This emphasis on the relationship among identity, biography, and history reinforces the value of autobiographies and life stories.

My selection of women's autobiographies is part of the feminist effort to illuminate the family as a complicated space of resistance to forms of race and class oppression. Women activists' lives demonstrate this complexity within the context of the family as a place where their initial experiences to resistance occur. These autobiographies center on women's status as "outsiders/within" in that women occupy insider status as members of the family but also experience expectations of subordination as a result of gender. Such an analysis suggests the ways in which women empower themselves to resist in such contexts.

My choice to focus on these particular women was due to the nature of their participation in the movements in which they were involved. They were all icons within their respective social movements. At the same time, their autobiographies attest that they faced issues of discrimination on the basis of gender both within and external to the movements in which they participated, and they were required to handle certain kinds of responsibilities because of their gender. They thus provide an excellent opportunity to examine issues of gender and to focus on "unofficial, private and seemingly invisible spheres of social life and organization" (Hill Collins, 2000, p. 202).

I chose to analyze and compare the autobiographies of African American and Black South African women because they allow for the examination of experiences of Black women involved in comparatively similar resistance struggles to draw transnational comparisons of family influence and activist identity development. The social conditions of Apartheid and Jim Crow segregation, both in their institutionalized and noninstitutionalized forms, have similar social structures created to emphasize white supremacy. Much comparative work between the two movements presents an analysis of the nature of racism (Berkhoffer, 1981; Bundy, 1990; Cell, 1982; Frederickson, 1981, 1995; 
Giliomee, 1981; Greenberg, 1980; Marx, 1998; VanDenBerghe, 1967), exploring the comparisons between these social structures and the creation and implementation of white supremacy. Although Frederickson (1995) suggested that the United States and South Africa influenced one another such that "black South Africans often cited the progress of blacks in the United States to show what black people were capable of accomplishing" (p. 5), little work has explored the resistance movements of Black South Africans and African Americans in their respective systems of oppression. This analysis will provide a starting point for understanding similarities and perhaps reciprocity in the resistance strategies of the two movements.

A brief explanation of each activist-autobiographer provides a clearer sense of the rich data they provided for my study. While the material that has been written about these women has focused on the men to whom they were romantically partnered, they are worthy of analysis as activists in their own right. Frances Baard served as a leader in the South African anti-Apartheid movement through her participation in the African National Congress (ANC). She was an organizer of the ANC Women's League (ANCWL) and became secretary and treasurer of the League's Port Elizabeth branch. She participated in the Federation of South African Women (FSAW), the South African Congress of Trade Unions (SACTU), and the United Democratic Front. She was also particularly active in the 1952 Defiance campaign, was a major organizer of the anti-pass campaign, and served as co-creator of the Freedom Charter.

Mamphela Ramphele, a physician with a doctorate in social anthropology, is a civil rights community development worker who is committed to the health and social welfare of the poor in South Africa. She was an activist in the Black Consciousness Movement (BCM) as a member of the South African Student Organization (SASO) and served as manager of the Eastern Cape branch of the Black Community Health Programme.

Winnie Mandela, a medical social worker, participated in the anti-pass campaign, served as the chair of the Orlando West branch of the African National Congress (ANC) and the African National Congress Women's League (ANCWL) and eventually served as president. She was particularly active in the Soweto student uprising in 1976. She spent several years under banning orders, in solitary confinement and in exile for her political activity. She was eventually arrested and charged with perpetuating communism.

The women who represent the U.S. movement participated in a variety of organizations, but their work was directly related to the after-effects of the antisegregationist practices of the 1960s and 1970s. These women include Angela 
Davis, a student of Herbert Marcuse, who earned a doctorate in philosophy. She was active in the Student Nonviolent Coordinating Committee (SNCC) and participated in both the Black Panther Party of Northern California and in the Black Panther Party for Self-Defense; she also was a member of the American Communist Party. Through her work in these organizations, she began to work on behalf of political prisoners.

Elaine Brown, an accomplished musician, began her activism as a member of the Black Congress, a conglomeration of Black organizations in the Los Angeles area whose aim was to serve the needs of Black people. She worked for the Black Congress newspaper Harambee and, during her tenure with the Black Panther Party, was the editor of the Black Panther newspaper. Within the party, she also held the positions of deputy minister of information, chairperson and minister of defense, and party chief. She was active in the survival programs of the organization that expanded services to the community, such as the free-breakfast program, free legal and medical clinics, and the Oakland Community Learning Center. She eventually ran for political office and was a delegate to the California Democratic convention in 1976.

Assata Shakur was an activist in the student rights movement, especially active in the Oceanhill/Brownsville community uprising for public control of schools. In her involvement in the Black Panther Party, she became connected to the more politically radical Black Liberation Army (BLA). Living in Cuba in political asylum since 1979, she was arrested and convicted of charges stemming from an incident on the New Jersey turnpike that left a state trooper and a fellow BLA member dead. She was also active in the anti-Vietnam movement, the movement for welfare recipients' rights, free breakfast programs in poor Black neighborhoods, and movements on behalf of prisoners' rights.

The autobiographies were analyzed to identify examples of resistance and strategy using a textual analysis consistent with grounded theory (Glaser \& Strauss, 1967). I analyzed these autobiographies focusing on their descriptions of encounters with family members in moments of resistance, paying particular attention to the types of influences they described. This method focuses on theory generation rather than on theory verification. The researcher does not undertake the research task with hypotheses in mind that are to be either verified or rejected. Rather, the undertaking is focused on the systematic view of data that will result in the development of propositions or hypotheses about them. The researcher provides evidence for the existence of these propositions but does not endeavor to test them empirically at this stage. 
Because my interest in this study was in discovering how these social activists describe familial influences on the development of their activist identity, I coded my data by identifying passages in the autobiographies in which the authors explicitly mention family members in relation to incidents of resistance. I then labeled the different types of resistance in incidents and compared and contrasted these passages in an inductive process, sorting them into similar categories, whereupon I developed a schema from the relationships among categories of familial influence. This process revealed four types of influencefamilial modeling of resistance, familial generation of resistance, discursive construction of families, and redefinition of conventional family forms.

\section{Family Influences}

An analysis of the autobiographies of Black South African and African American women suggests four types of familial influence on resistance identity and strategies. Black women discuss and reflect on the strategies of familial modeling of resistance, familial generation of resistance, discursive construction of families and redefinition of conventional family forms.

\section{Familial Modeling of Resistance}

Familial modeling of resistance involves the activists' identification with family members' acts of resistance as influential to the development of their political consciousness. As a strategy, activists attribute familial influence to their later defiance and protest activities to the models of such activities provided in their own families. This modeling assumes the form of actually witnessing resistance by family members and developing, through family interaction, the self-confidence required for resistance.

The authors of the autobiographies suggest the significance of family members, both distant and immediate, on their revolutionary ambition. The autobiographers described situations where their family members-whether grandparents, parents, siblings or even their own children-modeled resistance behaviors. While some of the examples are individual moments of resistance, others are more symbolic.

Many of the activists attributed the development of their political consciousness to family members. Ramphele, for example, mentioned that her political awareness began when she overheard a conversation between her parents:

My introduction to politics was a silent one. I remember my parents discussing politics in hushed tones, particularly after my 
aunt's husband had been detained under the 90-days detention clause which the Nationalist government introduced to deal with rebellion against their authoritarian rule. . . . My uncle Solly Mogomotsi was a member of the ANC and had been a member of the South African Communist Party before it was banned in 1950 (p. 28).

The activists frequently focused on their mothers as particular models of resistance. Ramphele reported that her mother demonstrated resistance strategies against traditional roles of women, with the acceptance and approval of a female audience:

She calmly walked up to the men's fireplace and carried away the pot containing the meat with tender portions which was ready for consumption. . . No woman had ever dared to touch a pot cooked by men. The other women, including my grandmother, were jubilant that the spell had been broken. From then on there was greater cooperation between men and women with the slaughtering. . . The men gave the women more control over the rest of the meat. My mother's transgressive act had liberated both men and women in the extended family from an archaic custom. (p. 15)

Similarly, Brown discussed how her mother was committed to enrolling her into an experimental private elementary school that had a four-year waiting list so that her daughter would have an opportunity to excel:

My mother was determined, however, that I could go there right away; there would be no waiting list for me. She fired off letters to the school board and made personal appearances at its meetings. She sought out and got support for her cause from locally prominent colored people. Nearly everyday, she would call every colored professional she knew of . . . . She would implore them to understand how hard it was for an ordinary working woman like herself to provide anything decent for her child, how hard it was for her to even keep her head above water as a woman alone. ... One by one they were pressed into service. ... When she was finished, I was enrolled. (Brown, p. 23)

In some families, stories and lore had developed around the resistance activities of family members. Shakur described her Uncle Willie's resistant behaviors and refers to him as "something as a legend" (p. 22). She said, "he 
would go around demanding his rights and denouncing the oppression of black people" (p. 22). While she clearly admired him and saw him as a role model, she also expressed the family's fear for his safety: "it is logical that no one who loved him felt the least bit comfortable until he was long gone" (p. 22).

A second way in which familial modeling contributes to the development of resistance activities is through familial emphasis on particular internalized principles that can be identified as essential to an internal locus of resistance. As a strategy, family members often encouraged a sense of self-pride, confidence, respect, and other attitudinal characteristics important to the development of an activist identity.

One of the qualities crucial to the development of this identity is dignity. Shakur remembers her grandparents emphasizing several personal principles that in some way contributed to her political development: "All of my family tried to instill in me a sense of personal dignity, but my grandmother and my grandfather were really fanatic about it. Over and over they would tell me, 'you're as good as anyone else. Don't let anybody tell you that they're better than you.'” (p. 19).

The activists' families not only fostered dignity but required that the women act in ways consistent with that dignity. Shakur's grandparents, for example, demanded that she behave in ways that commanded respect. Considering this was a behavior for which she could have been severely punished by Whites, Shakur's grandparents insisted, under the threat of violence, on behavior that was counter to the racially acceptable social norms of the time. She explained:

My grandparents strictly forbade me to say "yes ma'am" and "yes sir" or to look down at my shoes or to make subservient gestures when talking to white people. "You look them in the eye when you talk to them" I was told. "And speak up like you've got some sense." I was told to speak in a loud, clear voice and to hold my head up high, or risk having my grandparents knock it off my shoulders (p. 19).

Familial modeling of resistance provides activists with examples of political activism and encouragement to assume similar personas. Family members demonstrate political involvement and resistance that, activists suggest, influence their own political development. In addition, family members insist on the development of specific personality characteristics that contribute to the activists' self-confidence, thereby contributing to their activist identity. 


\section{Familial Generation of Resistance}

Not only do families contribute to the development of transgressive cognizance but the family itself also can serve as a place in which resistance is practiced. In these cases, the activists resist family members and demand change within their families. In essence, they learn how to resist by engaging with their own parents and working against class distinctions, gender roles, and racial social norms within their families.

In some instances, the resistance is rooted in preferences for various kinds of politically motivated alliances. Shakur, for example, was both confused by and disagreed with her grandmother's desire for her to associate with the children of the Black elite of Wilmington:

My grandmother would chirp for a week about how nice my little decent friends were and about how nicely we had played together, while I would groan silently and keep the expression on my face one shade away from insolence. My grandmother and I waged a standoff battle damn near until I was grown. It wasn't that I wanted to defy her, it was that I just liked who I liked. I didn't care what kind of house my friends had or whether or not they lived in alleys. (p. 22)

Ramphele presented a direct challenge to her father as she described her occupational choice as conflicting with her father's plans for her. She described her father's attempt to encourage her to pursue a career that was more practical for women at the time: "My father had good reason to dissuade me . . . . His suggestion was that I choose teaching as a quick route to earning an income in order that I might help my mother support the rest of my siblings. I argued that if I were to follow my own chosen career, I would in the long run be of greater assistance to my mother" (p. 45).

For some, resistance assumes a challenge to traditional gender roles and restrictions within the family; in these cases, the resistance is to the women's husbands. Baard described a situation in which the husbands of a group of women she was attempting to mobilize for the Women's League of the ANC forbade their wives to attend meetings out of concern for their safety:

Some of the women couldn't come to the meetings. Sometimes you would be talking to a woman, telling her about the organization, and then she would say, "my husband doesn't want me to go to meeting. . . ." You know what men are-some 
of them didn't understand what was happening and they would refuse for their wives to go. They would say, "well, you must look after your children, look after your house. I have no time for what you are trying to do.". . . Then we tell them that we make it our duty to escort them home. We always come home in groups from the meetings. We go with one woman to the gate of her house and we say goodbye, and we leave her there. Then we go with the next one to her house. We always made sure that everyone got home safely. (p. 37)

Familial generation of resistance describes how activists resist against family members. Either in reaction to traditional roles or through identification with others, activists demonstrate personal and political autonomy and practice resistance as a major step in activist identity development.

\section{Discursive Construction of Families}

A third type of familial influence on the development of an activists' identity occurs in the use of familial language to create family-like connections. Inherent in these examples is the appropriation of familial references to those with and for whom they struggle as a way to forge connections with other movement participants.

Activists in both struggles - the BPM in the U.S. and the BCM of South Africa-used familial concepts such as "brother" and "sister" in reference to their comrades. Brown mentioned not only the use of such terms but suggests the sense of inclusion that results from their use: "he called me 'sister' so genuinely, so purposefully, it was not an appellation but an affirmation" (p. 105). Davis reinforced this idea when she elucidated the feelings of elation experienced by fellow protestors while participating in grassroots organizing: "we experienced the heights of brotherhood and sisterhood doing something openly, freely and above ground about our own people" (p. 170).

Not only sibling terms but maternal terms are used in reference to fellow activists. Mandela, for example, described a maternal relationship in reference to a fellow comrade: "Helen Joseph, whom I have regarded completely as my mother, because of what she has meant to me not only politically, but from a completely human point of view" (p. 66).

Familial language also entails a deep commitment to the work and emotional ties to fellow activists, not unlike the commitment and emotional ties that characterize families. This emotional connection illustrates the strong sense 
of family that is often described as essential to the struggle for social justice. Shakur, for example, felt the familial ties so deeply that they provided her life with meaning. Here she presented an example of these emotional ties using the metaphor of home and family:

The more active I became the more I liked it. It was like medicine, making me well, making me whole. I was home. For the first time, my life felt like it had some real meaning. Everywhere I turned, black people were struggling, Puerto Ricans were struggling. It was beautiful. I love black people, I don't care what they are doing, but when black people are struggling, that's when they are most beautiful to me. (p. 189)

In other situations, an awareness of others and a sense of familial responsibility are identified as a motivation for political transformation, as in Brown's case. While volunteering to teach piano lessons to a group of girls who lived in a housing tenement in Watts, she felt guilt and a filial sense of obligation to the girls and ultimately to the larger liberation movement:

I wanted to fall to my knees and ask them for forgiveness. I wanted to beg them to forgive me, for I had tried to forget. I wanted to beg them to forgive me for leaving them for so long. . .

. I wanted to beg them to be patient with me, for I had to go back there again if I ever wanted to be free of all the pain of my life (pp. 101-102).

Use of familial terms is significant in that it demonstrates a sense of belonging to the movement-a belonging nearly as significant as that which characterizes the family. These terms illustrate the importance of the relationships within their various organizations as a mechanism to foster activism.

\section{Redefinition of Conventional Family Forms}

Redefinition of conventional family forms is a fourth way in which the family influences and is influenced by the resistance identities of the activists. In these innovative families, activists emulate and create a world in which the type of equality for which they fight is realized. The new family forms they develop challenge the traditional family structure and represent a new conceptualization of family and traditional gender roles. Examples of the redefinition of family forms range from decisions to bear children for the revolution to the reconceptualization of motherhood to the creation of new family forms. 
Embedded in these autobiographies is a juxtaposition between acceptance of and challenge to traditional gender roles and particularly to the role of motherhood. Typical of many nationalist movements, women involved in liberation struggles are expected to reproduce "soldiers for the revolution." Once the children are born, however, these activists create various support mechanisms to provide for their children while they continue their professional and political work. In other words, they do not themselves assume traditional maternal roles in relation to their children.

Brown explained the expectations of women within the BPP to produce children for the cause: "our gender was but another weapon, another tool of the revolution. We also had the task of producing children, progeny of revolution who would carry the flame when we fell, knowing that generations after us would prevail' (p. 137). Shakur reinforced the idea that women are seen as mothers of the movement but also as mothers of the next generation of revolutionaries. When she discovered that she had conceived a child while she was on trial for bank robbery, she explains her pregnancy in this way: "I'll tell them that this baby was sent by the Black creator to liberate black people. I'll tell 'em that this baby is the new black messiah, conceived in a holy way, come to lead our people to freedom and justice and to create a new black nation" (p. 123).

Even as they recognize their responsibility to be mothers, the activists realize that within the conditions of their activism, which in some cases involve incarceration, they cannot occupy traditional roles of motherhood. This redefinition of motherhood appears not only to be a personal and political necessity, but it is also a way in which these women discuss the importance of children-all children-to the movement. New conceptualizations of motherhood range from employing others to assume primary childcare duties to the South African cultural tradition of adopting wives.

Some of the activists are very comfortable with their redefinition of motherhood. Ramphele, for example, recognized the importance of having parental support to raise her children and connected the supportive child care with the traditional role of "wife": "Unlike a lot of other women in my position, I have no guilt feelings about my domestic arrangements. . . I am indebted to all those women who have played this effective wife role in my life (p. 174). In contrast to Ramphele, Mandela described the internal struggle associated with this redefinition of parenthood and the effects of political participation on the children: "it is very hard for a mother, especially in a state of perpetual war where I cannot give them any kind of security . . the children were petrified . . . no amount of explanation could reassure them because I had no protection. . . 
they knew we loved them but we were never there to express it-it was love by proxy" (p. 90).

In creating new family forms, activists challenge traditional definitions of family. In doing so, they create mutually supportive relationships with others to which they are politically but not biologically related and to whom they feel emotionally connected and responsible. In addition, they redefine maternal roles by developing relationships that facilitate their participation in political and professional endeavors and by contributing to the liberation struggle through their conception of future activists.

\section{Conclusion}

In this essay, the autobiographies of Black South African and African American activists were analyzed to explore familial influence on the development of activist identity. The findings suggest that families serve as a training ground for people not only to learn the nature and function of oppression but also to learn to resist. Families, in other words, present a unique structure in which activists learn to define themselves and develop their efficacy. The four familial influences on this transformation are familial modeling of resistance, familial generation of resistance, discursive construction of families, and redefinition of conventional family forms. These activists, then, learn how to resist external family structures, they learn how to resist within the family, and they create new kinds of families that support their activist identities.

The four mechanisms suggest a two-stage identity process for the creation of activist identities derived from the family. The first stage includes the modeling of an activist identity. The family models and encourages the adoption of a political consciousness and individual behavioral constructs that foster the development of an activist identity within a context that is supportive and comfortable. Within the family, individuals are being coached how to resist and are provided with the tools needed for this resistance. In other cases, activists encounter disconfirmation and must resist their own family members. This, too, is a form of coaching in that this disconfirming feedback mimics that to which they will be exposed when confronting larger structures of oppression outside of the family. In either case of confirming or disconfirming feedback, these activists develop the confidence required to assume transgressive roles.

The second stage of activist identity formation is the strategic creation of new social networks that challenge and often replace traditional family roles. Here activists align with others to develop new family structures that encapsulate a creative identity, one in which they invent family structures that encompass the 
totality of their struggle for personal and political freedom. With these structures, the activists move beyond resistance to create new structures that allow them to enact their liberatory desires. In constructing these new familial relations, they focus on a more egalitarian society, defining for themselves the new ways of living that mark such a society.

The two-step process suggested by this analysis, in which individuals begin the development of activist identities by learning how to resist and then move to the creation of emancipatory structures themselves, suggests some tentative conclusions about the maturation of the activist identity. As individuals move from the resistance training embodied in familial modeling and generation of resistance to familial innovation, their identities as activists are evolving in significant ways. They move from an environment of safety-the safety and comfort of the home and family - to uncharted territory in which they must take risks and create structures not bound by hegemonic convention. The move requires courage and fearlessness, and those traits see development in this twostage process. The evolutionary movement also requires that the activists move from a concern with gaining the approval of others to a state in which that approval is irrelevant. They must break the bonds that a desire for approval entails in order to develop new structures and ways of being. The movement also involves a starting place of individual focus and an ending place of collectivity. As the activists move to this second stage, they are able to be more effective as they join with others in their struggle.

This exploratory research offers only a glimpse into the mechanisms by which families foster the development of activists' identities. It suggests the need for further analysis of the significance of the family on resistance. With the expansion of an understanding of familial influences on resistance, we begin to understand the complexities of women's activist identities and the contexts in which their activism takes place. 


\section{References}

Aulette, J., \& Mills, T. (1988). Something old, something new: Auxiliary work in the 1983-1986 copper strike. Feminist Studies, 14, 251-68.

Baard, F. (1986). My spirit is not banned. Harare, Zimbabwe: Zimbabwe Publishing.

Baca Zinn, M. (1975). Political familism: Toward sex-role equality in Chicano families. Aztlan-International Journal of Chicano Studies Research, 6, 1, 13-26.

Baver, S. L. (1989). Political participation of Puerto Rican women: Mapping a research agenda. Affilia, 4, 59-69.

Berg, B. (2001). Qualitative research methods for the social sciences (4th ed.). Thousand Oaks, CA: Sage.

Berkhoffer Jr., R. F. (1981). The North American frontier as process and context. In H. Lamar \& L. Thompson (Eds.), The frontier in history: North America and South Africa compared (pp.43-75). New Haven, CT: Yale University Press.

Bookman, A., \& Morgen, S. (Eds.) (1988). Women and the politics of empowerment. Philadelphia: Temple University Press.

Brown, E. (1994). A taste of power: A Black woman's story. New York: Anchor.

Beuchler, S. M. (1993). Beyond resource mobilization? Emerging trends in social movement theory. Sociological Quarterly, 34, 217-235.

Bundy, C. (1990). An image of its own past? Towards a comparison of American and South African Historiography. Radical History Review, 46(7), 117-143.

Caulfield, M. (1975). Imperialism, the family, and cultures of resistance. Socialist Revolution, 20, 67-85.

Cell, J. (1982). The highest stage of White supremacy: The origins of segregation in South Africa and the American south. Cambridge, MA: Cambridge University Press.

Cohen, J. (1985). "Strategy or identity: New theoretical paradigms and contemporary social movements." Social Research, 52, 663-716.

Davis, A. (1974). Angela Davis: An autobiography. New York: International Publishers.

Foweraker, J. (1995). Theorizing social movements. London: Pluto Press.

Frederickson, G. (1981). White supremacy: A comparative study in American and South African History. Oxford, UK: Oxford University Press

Michigan Family Review, 10, 27-44, 2005 C Michigan Council on Family Relations 
Frederickson, G. (1995). Black liberation: A comparative history of Black ideologies in the United States and South Africa. New York: Oxford University Press.

Giliomee, H. (1981). Processes in development of the South African frontier. In H. Lamar \& L. Thompson (Eds.), The frontier in history: North America and South Africa compared (pp.76-119). New Haven, CT: Yale University Press.

Glaser, B., \& Strauss, A. (1967). Discovery of grounded theory: Strategies for qualitative research. Chicago: Aldine Press.

Greenberg, S. (1980). Race and state in capitalist development: Comparative perspectives. New Haven, CT: Yale University Press.

Hill-Collins, P. (2000). Gender, Black feminism, and Black political economy. Annals, American Academy of Political and Social Science, 568.

Hill-Collins, P. (2000). Black feminist thought: Knowledge, consciousness and the politics of empowerment. New York: Routledge.

Kimble, J. \& Unterhalter, E. (1982). "We opened the road for you, you must go forward": ANC women's struggles, 1912-1982. Feminist Review 12, 11-33.

Kuumba, M. B. (2001). Gender and social movements. New York: Alta Mira Press.

Marx, A. (1998). Making race and nation: A comparison of South Africa, the United States, and Brazil. New York: Cambridge University Press.

McAllister, P. (1991). This river of courage: Generations of women's resistance and action. Philadelphia: New Society Publishers.

Mandela, W. (1985). Part of my soul went with him. New York: Norton.

Mashinini, E. (1991). Strikes have followed me all of my life. New York: Routledge.

Merton, R. (1988). Some thoughts on the concept of sociological autobiography. In M. White-Riley (Ed.), Sociological lives (pp. 17-21). Newbury Park, CA: Sage.

Mills, C. W. (1959). Sociological imagination. New York: Oxford University Press.

Naples, N. (1991). "Just what needed to be done": The political practice of women community Workers in Low-Income Neighborhoods. Gender \& Society, 5, 478-494.

Noonan, R. (1995). Women against the State: Political opportunities and collective action frames in Chile's transition to democracy. Sociological Forum 10, 81-111. 
Pardo, M. (1990). Creating community: Mexican American women in Eastside Los Angeles. Aztlan, 20, 39-71.

Shakur, A. (1987). Assata Shakur: An autobiography. Westport, CT: L. Hill.

Strauss, A. (1995). Identity, biography, history, and symbolic representations. Social Psychology Quarterly, 58, 4-12.

Tarrow, S. (1995). Cycles of collective action: Between moments of madness and the repertoire of Contention." In M. Traugott (Ed.), Repertoires and cycles of collective action (pp. 89-115). Durham, NC: Duke University Press.

Taylor, V. (1995). Watching for vibes: Bringing emotions into the study of feminist organization. . In M. M. Ferree \& P.Y. Martin (Eds.), Feminist organizations: Harvest of the new women's movement (pp. 223-233). Philadelphia: Temple University Press.

Taylor, V. (1997). Social mobilization: Lessons from the mass democratic movement. Bellville, South Africa: University of the Western Cape.

Van Den Berghe, P. (1967). Race and racism: A comparative perspective. New York: Wiley.

Walker, C. (1982). Women and resistance in South Africa. London: Onyx Press. 